QK

525.5

.177

C56

1898

Clute, Willard Nelson

The ferns and fern allies of the upper Susquehanna valley 



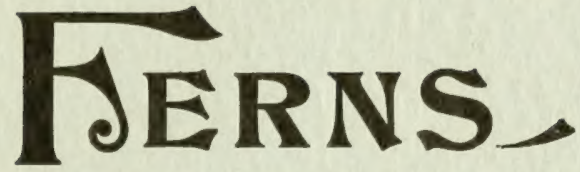

.. OF THE ...

\section{...UPPER ..SUSQUEHANNH...}

BY WILLARD N. CLUTE.

BINGHAMTON, N. Y.

WILLARD N. CLUTE \& CO. I 898 . 

THE

\title{
FERNS AND FERN ALLIES
}

\author{
OF THE
}

\section{UPPER SUSQUEHANNA VALLEY,}

WILLARD N. CLUTE.

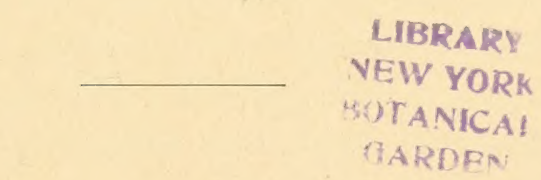

Reprinted, with Notes,

FROM

"The Flora of the Upper Susquehanna."

BINGHAMTON, N. Y. :

WILLARD N. CLUTE \& CO.

3808 . 


$$
\begin{aligned}
& \text { QK525.5 } \\
& \text { NT } \\
& C 56 \\
& 1898
\end{aligned}
$$




\section{PREFATORY NOTE.}

THIS list is reprinted, with notes, from the author's volume on the "Flora of the Upper Susquehanna Valley." So many requests have been received for a list of the ferns of our locality that it has seemed expedient to publish one at this time. The area covered comprises a stretch of country about 150 miles long and from one-third to one-quarter as wide, lying mostly in Southern New York. It consists of the area about the headwaters of the Susquehanna, including the Chemung and Chenango. This district contains very little broken country, and the rock outcrops are all sandstone or shale. The nomenclature used in this list is that of the "List of Pteridophyta and Spermatophyta," published as volume five of the memoirs of the Torrey Botanical Club. When these names differ from those in Gray's Manual, sixth edition, the latter names follow the remarks in parenthesis. The observers cited as authority for some of the statements are Mr. F. V. Coville, Dr. T. F. Lucy, Prof. Frank E. Fenno, Mr. James A. Graves, Mr. W. C. Barbour, and Miss S. A. Brown. For a more extended account of the general characteristics of our region, readers are referred to the introduction to the Flora.

WILLARD N. CLUTE. 



\section{LIST OF SPECIES.}

\section{EQUISETACEAE.}

\section{EQUISETUM L.}

E. arvense L. Fieli) HoRsetall. Very common throughout in any kind of soil. Fertile stems early in spring, brown in color. Sterile, later, much different in appearance from the others. 'This species when growing in thin, sandy soil, is quite changed in appearance. Instead of an erect central stem, it becomes nearly or quite prostrate. The so-called variety campestre is often found. In this the normally sterile fronds bear small fruiting spikes at the summit. The fertile stems occasionaliy have a few green branches at the base. Gray's Manual says the rootstock occasionally bears tubers.

E. sylvaticum L. Won Hursetail. Abundant in moist woodlands. Sterile stems producing several very regular whorls of branches, which are again branched. The most beautiful member of the genus in our region. It thrives well in cultivation if given shade and moisture.

E. fluviatile L. Pipes. Sivamp Horsetail. Plentiful on the borders of lakes, streams and ditches, often in shallow water. Stems frequently unbranched, but usually producing a few straggling branches near the summit of the stem. So many forms of this species occur, according as it is branched or unbranched, that it often appears like another species. It is one of the commonest of plants along the Susquehanna. (E. limo. sum L. )

E. hyemale L. Scouring Rush. Shave Grass. Plentiful in low woodlands, on the banks of streams, and other moist places. Stems commonly unbranched, stiff, two feet or more high, persisting through the winter. In winter the hollow stems are 
filled with a solid core of ice. Although a lover of moisture, this species is often found in dry situations, such as railway embankments.

E. variegatum Schleich. Rare. Brisbin swamp on the margin of a sand slide, Coville. The only station.

\section{FILICES.}

\section{POLYPODIUM L.}

P. vulgare L. COMMON POLYPoDr. Plentiful in our region wherever outcrops of rock occur. Usually found growing on the tops of rocks where there is little moisture. Fronds nearly pinnate, evergreen, leathery; the large, round fruit dots on the under side of the fronds in late summer. Rootstocks covered with brownish scales and creeping extensively. Like some of its tropical relatives our species, when dry, curls up its fronds until the drouth is past.

\section{ADIANTUM L.}

A. pedatum L. Mallenhair Fern. Abundant throughout in moist, rich woodlands. Stipe a foot or more high, black and shining, divided at the top into two curving branches which bear the pinnæ. Fruit beneath a reflexed portion of the pinnule. In cultivation the fronds grow larger and stronger and are produced throughout the summer.

\section{PTERIS L.}

P. aquilina L. Bracken. BRake, EAgle Fern. Most abundant on scrubby hillsides, on the borders of fields, roads and in open woods. Stipe stout and tall, at top bearing three divisions, variously subdivided. Rootstock stout, deep in the earth, creeping extensively and bearing the fronds at intervals, all summer. Fruit produced in a line on the margin of the pinnules. It is difficult to make the bracken grow where wanted, and equaliy difficult to eradicate it when once it has gained a foothold.

\section{PELLEA LINK.}

P. gracilis (Michx.) Hook. Slenter ClifF-BrakF. The nnly station known for this fern within our limits is on a cliff at 
Killawog, in Broome county. It is there plentiful. Fruit nearly as in Pliris. This cliff is composed of shales, with perhaps a very slight amount of lime in them. The slender clifibrake is one of the few species that is supposed to be confined exclusively to limestone rocks, and its occurrence here is remarkable.

\section{WOODWARDIA J. E. SMITH.}

W. Virginica (L.) J. E. Smith. Virginian Chain-Fern. Rare. Brisbin peat-bogs, Corille. Thompson's Marsh, Clute. Beebe's swamp and swamp at Oakland, firazes. Bog north of Barton, Fenno. The only stations. Fronds in appearance very much like Osmunda Cinnamomea, except that they are borne singly and not in clumps and the fruit dots occur on the backs of fronds that resemble the sterile ones. In localities where one does not expect it, this is probably one of the easiest of species to overlook. Good botanists frequently pass through it thinkit an Osmunda.

\section{ASPLENIUM L.}

A. Trichomanes L. Maidenhair Spleenwort. Wall SpleenWORT. DWARF SPLEenworT. Fairly common on the rocky walls of nearly all of our deep ravines. Fronds seldom more than six inches long, pinnate, several from a common centre, forming green rosettes. Fruit dots linear, on the backs of the pinnæ. This species is a lover of the deepest shade, but thrives well under cultivation in a rockery.

A. platyneuron (L.) Oakes. Ebony Spleenwort. Common. Found only in rocky uplands in partial or complete shade. Stipe very short, it and the rachis black and polished. Fronds somewhat larger than the preceding, the sterile, half reclining; the fertile, later, erect and longer than the sterile ones. While never found growing on cliffs in our region, it still seems to need the touch of the rock. Given a hillside covered with loose shale, and this fern may be expected. (A. ebeneum Ait.)

A. angustifolium Michx. Narkm-Leated Spleenwort. In rich woods, Brown. Van Etten, N. Y., Barbour. The only stations. Fronds tall, thin, once pinnate, the fertile ones produced but sparingly. 
A. acrostichoides Sw. Silvery Spleenirort. Commonin rich, moist shades. Fronds two feet or more high, pinnate, the pinna pinnatifid; fruit borne on the back of the fronds, in a double row on each pinnule, silvery white when young. ( $A$. thelypteroides Michx.)

A. Filix=fomina (L.) Bernh. LAIY FERN. Abundant along roadsides, in thickets and in open woods. Well known. Quite variable in the form of the fronds. Fruit dots at first curved, at length straight, brown or blackish when ripe. It is usually a difficult matter to find a perfect frond of this species.

\section{CAMPTOSORUS LINK.}

c. rhizophyllus (L.) Link. WALking FeRn. WALKING-LEAF. Rare. Found only in a few restricted areas in our region. Lockwood, N. Y. ; scarce, Barbour. On rocks west of Barton; rare, Fenno. On sandstone rocks in various places about Susquehanna, Graves. South Oxford and on sandstone rocks in several places about Oxford, Coville. Fronds gradually narrowing from a heart-shaped base, into a long, narruw tip, which bends over and rooting at the apex, gives the common name to the fern. Fruit dots much like Asplenium. This is another lover of limestone that is found on shale or sandstone in our locality. Easily cultivated in the rockery.

\section{PHEGOPTERIS FEE.}

P. Phegopteris (L.) Underw. BeEch Fern. Common on wet rocks in sun or shade. Frond triangular in outline, longer than broad, bi-pinnatifid, the lowest pair of pinnæe standing forward. Fruit dots small, round, without indusium. This species particularly loves the wet soil at the base of cliffs, but will grow in almost any soil. An elegant species for the fern garden. ( $P$. polypodioides Fee.)

P. hexagonoptera (Michx.) Fee. Six-Angled Poly pody. Broad BeECH FERN. Tolerably common in ratherdry, rich woods. In appearance much like the preceding, except that the fronds are broader than long, the lowermost pair of pinnce much larger. their pinnules pinnatifid. This may be distinguished from the preceding by the odor of the bruised foliage. It is commonest in deep shade, but seldom occurs in coniferous woods. 
P. Dryopteris (L.) Fee. O.k Frik. Plentiful in rich, moist woods, occasionally in company with $I^{\prime}$. Phegoperis. Fronds small, quite like the bracken in miniature. 'This species is very pleasing in cultivation. Fronds are produced throughout the summer.

\section{DRYOPTERIS AUANS.}

D. Thelypteris (L.) A. Gray. LAM FERn. MARSH SHeli FERN. Abundant in swamps, wet woods and other low grounds. Fronds lanceolate, nearly twice pinnate on long stipes. Fruit on the back of fronds late in the season. In shade this fern is usually completely sterile. (Aspidium Thelypteris $\mathrm{Sw}$.)

D. Noveboracensis $\left(I_{\text {, }}\right)$ A. (iray. NEW YuRk FFrN. Common in moist woods, especially in uplands. Stipe short; frond very thin, tapering both ways from the middle. Distinguished from the preceding, which it closely resembles, by the thinner texture of the frond and by the pinnæe gradually narrowing to mere ears at base. The bruised foliage of this species is sweetscented, and forms another means of distinguishing it from D. Thelypteris. A delicate species. (Aspidium Novebora. censis Sw.)

D. spinulosa (Retz) Kuntze. Spinulose Shield.Fern. Not common. Found throughout, but much less common than the following sub-species. Fronds tall, ovate, bi-pinnate, the pinnules with spinulose teeth. The fronds are produced in early spring. several in a clump and are half evergreen. (Aspidium spinulosum $\mathrm{Sw}$.)

D. spinulosa intermedia (Muhl.) Underw. SPinilose ShieliFERN. One of the commonest of ferns. Found in woodlands wet or dry. Resembles D. spinulosa, but with the pinnæ and pinnules more crowded and finely dissected. A very pretty and decorative plant, excellent for growing in the outdoor fernery. (A spinulosum, var. intermedium D. C. Eaton.)

D. spinulosa dilatata (Hoffm.) Underw. Much less common than the type and usually found at higher elevations. It is a difficult matter for the beginner to properly separate Driopteris spinulosa from its varieties. The fronds vary somewhat in shape. and it is only with an abundance of material that one can distinguish the limits of the forms. (Aspidium spinulosum. var. dilatatum Honk.) 
D. Boottii (Tuckerm.) U'nderw. Boutt's Shielir-fern. Rare. Susquehanna, Graves. Pond Brook, Clute. The only stations reported. In appearance this fern is about half way between D. spinulosa and the following. Further study of the forms referred to these two ferns will doubtless discover more stations for the present species. (Aspidium Boottii'Tuckerm.)

D. cristata (L.) A. Gray. Crest Fern. Crested Shield-Fern. Plentiful in swampy woods. Fronds tall and narrow, lanceolate in outline, pinnate, their divisions pinnatifid, the lowest pair of pinna triangular. The sterile fronds are usually shorter and broader than the fertile and less erect In sheltered situations the fronds of this species are nearly evergreen. (Aspidium cristatum $\mathrm{Sw}$.)

D. cristata Clintoniana (D. C. Eaton) Underw. Rare. Swamp near the city of Binghamton, Clute. Unadilla Forks, Brown. The only stations recorded. The fronds of this fern are in every way larger than the preceding, which it otherwise much resembles. Closer observation of our ferns will probably bring to light other stations for this one. (Aspidium cristatum, var. Clintonianum D. C. Eaton.)

D. Goldieana (Hook) A. Gray. Goldie's Shield-Fern. Rare. In'swampy ground east of Van Etten. Chemung county, N. Y., Barbour. Near Unadilla Forks; not common, Brown. The only stations. This fern may occur at other points within our limits and should be looked for in cold, wet woods. In appearance it is considerably like the following and might be mistaken for a large form of it. (Aspidium Goldieana Hook.)

D. marginalis (L.) A. Gray. Marginal Shield Fern. EverGReEN Wood-Fern. Abundant in deep shades. Fronds two feet or more high, about twice pinnate. Well known for the bright, white covering of the fruit dots, which are borne on the back of fronds like the sterile ones. The fronds remain green through the winter, but are usually prostrated by wind and snow. 'This fern will endure much more in the way of light and dryness than most of its relatives, and is excellent for the fernery. (Aspidium marginale Swartz.)

D. acrostichoides (Michx.) Kuntze. Christmas Fern. Abundant throughout our range, especially in evergreen woods. Fronds thick, evergreen, pinnate, the fertile contracted at the 
summit. Among the earliest of our ferns to fruit. 'The variety' incis $r$ is occasionally found with the type, and differs from it in having the pinnic much incised and in fertile fronds, nearly all of them fruit-bearing. This species is one of our best known ferns and is much used for holiday decorations. (Aspidium acrostichoides $\mathrm{Sw}$.)

\section{CYSTOP'TERIS BERNH.}

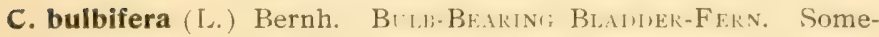
what rare. Oxford, Coville. Killawog, N. Y., Clute. Cascade, near Susquehanna, Graves. North of Apalachin, Fenno. Ravines at Unadilla Forks, Brown. Elsewhere not reported. Found usually on cliffs. Fronds very long and narrow, prostrate or pendant, bi-pinnate. In addition to fruit dots, the fronds usually bear bulblets on the backs. New plants are formed readily from the latter, and it is probable that this is the fern's principal method of reproduction.

c. fragilis (L ) Bernh. Fragile Bladder Fers. Brittle Fern. Common in wet, shaded soil, especially on cliffs. Fronds rather slender, nearly a foot long, twice or thrice pinnate.

\section{ONOCLEA L.}

0. sensibilis L. Sensitive Fern. Very abundant. Found on the borders of ponds and streams and in all low grounds. Sterile fronds broad and coarse; fertile fronds later in the season, their segments contracted into berry-like bodies which enclose the fruit. The fertile frond, remain erect through the winter. The so-called variety obtusilobata is occasionally found. In appearance it is half way between the fertile and sterile fronds of this species, and can be produced at will by removing the sterile fronds early in the season. The second or third crop of fronds will take on this shape.

O. Struthiopteris (L) Hoffm. Ostrinfin Fr.. Abundant. Found in alluvial soil along our larger streams. Fronds in a circular clump, often twenty or more from the same root, pinnate, the divisions pinnatifid. The fertile fronds appear late in summer from the midst of the sterile ones, much different in appearance. The rootstock sends out long. slender stolons, which form new 
plants at their ends. Our tallest and handsomest fern, often six feet high. Probably more of this fern is used in cultivation in our region than any other.

\section{WOODSIA R. BR.}

W. Itvensis (L.) R. Br. Rusty Polypod. Exposed rocks, summit of Mt. Markham, Unadilla Forks, Brown. The only station.

W. obtusa (Spreng.) Torr. Obtuse Woodsia, Rare. Found occasionally on the rocky walls along the Susquehanna below Towanda, Clute. Elsewhere not reported. In aspect this is much like Cystopteris fragilis, and at first glance might be mistaken for that species.

DICKSONIA LHER.

D. punctilobula (Michx) A. Gray Hay-Scented Fern. FineHaired Mountain Fern. Plentiful. Found in open woods and thickets especially in wilands. Fronds two or three feet long. very finely cut, usually growing in dense patches. Some of the higher elevations in our region are so thickly covered with this species, that it excludes everything else. In the upland pastures, its favorite habitat is under the edges of boulders, and the peculiar green of its fronds is noticeable from a great distance. Fragrant in drying. (D. pilosiuscula Willd.)

\section{LYGODIUM Sw.}

L. palmatum (Bernh.) Sw. Climbing FERN. "McDonough, Chenango county (Mrs. D. B. Fitch.) 'This is the second station in which this fern has been found in our State."-Annual Report State Botanist, 1893 .

\section{OSMUNDA L.}

o. regalis L. Flowering Fern. Royal Fern. Plentiful in swamps and wet, open woodlands, often growing in shallow water. Fronds very smooth, twice pinnate, the pinnules oblong. Fruit borne in a panicle at the summit of some of the fronds. An elegant species, much less like the popular conception of a fern than most of our common species.

o. Claytoniana L. Interrupted Flowering Fern. Clayton's FERN, Common in low grounds, especially in thickets along streams. Sterile fronds once pinnate, the pinnæ pinnatifid. 
Fruit borne on two or more pairs of much contracted pinnic in the middle of an otherwise unchanged frond. This species fruits as the fronds unroll.

o. cinnamomea L. CINNAMON FERN. Very common in all low grounds. Fronds in a circular clump, the sterile pinnate with the pinnat pinnatifid, the fertile fronds much contracted, covered with cinnamon-colored sporangia, appearing earlier than the sterile ones. 'The fronds of this species are occasionally used as a pot-herb, being picked as they begin to unroll in spring. The so-called variety fronctosa is a form midway between the fertile and sterile fronds.

\section{OPHIOGLOSSACEA.}

\section{BOTRYCHIUM Sw.}

B. simplex E. Hitchcock. MoonworT. Swamp at the head of Bennett's Lane, Oxford, I886, Coville. Unadilla Forks; rare, Brown. The only stations.

B. lanceolatum (S. G. Gmel.) Angs. Laxceolate Moonwort. Woods at base of Mt. Markham, Brown. In the same situations as the following and almost invariably accompanying it, Cuville.

B. matricarixfolium A. Br. Rare. Woods at base of Mt. Markham, Brown. Beech and maple woods at various points in Oxford and Preston, Coville.

B. ternatum ('Thunb.) Sw. Ternate Moonwort. Grape Fern. Plentiful on dryish knolls. Sterile portion of the plant broadly triangular, ternate and variously divided. Fertile portion erectof ten four times pinnate. Our common form of the plant may be referred to the variety obliquum. A form with the segments cut into narrow lobes or teeth is occasionally found and is the variety dissectum. This species is excellent for cultivation in the fern garden.

B. Virginianum (L.) Sw. Rattlesnake Fers. Gripe Fern. Virginian MooNwort. Common in rich, moist woods throughout our range. In appearance like the preceding, except that the plant is taller with thinner fronds. It is found much earlier in the season than $B$. ternatum. There is a wide difference in the size of the fruiting fronds of this species which does not seem to be due to any outward cause. 
 \\ OPHIOGLOSSUM L.}

0. vulgatum L. AdDer's-Tongle Fern. Occasional in moist, grassyopenings of woods in northern Chenango county, Coville.

\section{LYCOPODIACE $A$.}

\section{LYCOPODIUM L.}

L. Iacidulum Michx. Shinina Club Muss. Hemlock Club-Moss. Common in cold dark, woodlands. In appearance likened to the hemlock Bulblets, from which new plants are produced, are often borne in the axils of the upper leaves.

L. annotinum L. Stiff Club Moss. Rare. Balsam swamp. Pharsalia, Coville. Along Pierce Creek, two miles south of Binghamton, Clute. Low ground, one mile north of Apalachin. Fenno. The only recorded stations.

L. obscurum L. Ground Pine. Plentiful in moist, rich woods. In appearance somewhat like a miniature pine tree, especially the variety dendroideum, which frequently occurs. This anr the two following species are much used in decorations for the winter holidays.

L. clavatum L. Common Club-Moss. Running Pine. Plentiful throughout. Found in open woods, thickets, and along bushy roadsides. Stem creeping extensively, with similar ascending leafy branches; fruit borne in conspicuous cylindrical spikes, two or three on a slender peduncle. This species particularly loves the rocky uplands.

L. complanatum L. Ground Pine. Runving Pine. Cenar Club. Moss. Common in rather dry soil. In appearance this species has been likened to the cedar. Fruit as in the preceding. The variety chamacyparissus, with narrower and more erect branches, is occasionally found with the type.

\section{SELAGINELLACE $A$.}

SELAGINELLA BEAUV.

S. apus (L.) Spring. Creeping Selaginella. Common in pastures by the river at Unadilla Forks, Brown. The only station. This species very much resembles a moss, and has doubtless been overlooked in other parts of our range. 


\section{ISOETACEA.}

\section{ISOETES L.}

1. Engelmanni A. Br. Along the river at Apalachin, Fenno. Along the Susquehanna in gravelly soil, city of Binghamton, Clute. Elsewhere not reported. Plant sedge-like in appearance, and difficult to distinguish from the vegetation amid which it grows.

1. Engelmanni gracilis Engelm. Found with the type in very wet, shady places. Leaves few and very slender.

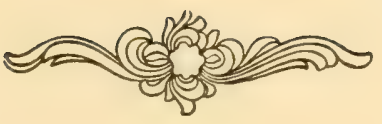







\section{QK525.5.N7 C56 1898}

Clute, Willard Nels/The ferns and fern a

(IIIIII 
